\title{
MicroRNA-183-5p promotes the proliferation, invasion and metastasis of human pancreatic adenocarcinoma cells
}

\author{
FEI MIAO ${ }^{1,2^{*}}$, JINHAI ZHU $^{1,2^{*}}$, YANLIN CHEN $^{1,2}$, NANHONG TANG $^{2}$, XIAOQIAN WANG ${ }^{2}$ and XIUJIN LI ${ }^{2}$ \\ ${ }^{1}$ Department of Hepatobiliary Surgery; ${ }^{2}$ Fujian Institute of Hepatobiliary Surgery, Fujian Medical University Union Hospital, \\ Fuzhou, Fujian 350001, P.R. China
}

Received October 20, 2014; Accepted July 16, 2015

DOI: $10.3892 / \mathrm{ol} .2015 .3872$

\begin{abstract}
The aim of the current study was to investigate the potential role of microRNA-183-5p (miR-183-5p) in the proliferation, invasion and metastasis of pancreatic cancer, and to identify promising target genes of oncogenic miR-183-5p. Western blotting and quantitative polymerase chain reaction (qPCR) were used to investigate whether these oncogenic microRNAs may be useful as biomarkers in pancreatic carcinoma $(\mathrm{PaCa})$. Potential target genes were verified using miRDB, PicTar and TargetSCAN, and qPCR was used to detect the expression of miR-183 and suppressor of cytokine signaling 6 (SOCS-6; a potential target of miR-183) in PANC-1 PaCa cells and in the HPDE6-C7 pancreatic ductal cell line for comparison. The function of miR-183 in cell proliferation, wound healing, invasion and migration was also investigated using a miR-183 inhibitor. Western blot analysis was used to confirm SOCS-6 as a tumor suppressor and qPCR was used to detect and confirm that this potential target gene is directly regulated by $\mathrm{miR}-183$. The results indicated that the expression of miR-183 in PANC-1 cells was upregulated compared with that in HPDE6-C7 cells, whilst the expression of SOCS-6 was downregulated. SOCS-6 expression was also significantly lower in $\mathrm{PaCa}$ tissues compared with that in matched normal pancreatic tissues from $\mathrm{PaCa}$ patients. Furthermore, expression of miR-183 was inversely correlated with that of SOCS-6. miR-183 knockdown decreased cell growth and motility in pancreatic cancer cells and significantly increased the expression of SOCS-6. These data suggest that oncogenic miR-183 may be useful as a pancreatic cancer biomarker. In addition, inhibition of
\end{abstract}

Correspondence to: Dr Jinhai Zhu, Department of Hepatobiliary Surgery, Fujian Medical University Union Hospital, 29 Xin-Quan Road, Fuzhou, Fujian 350001, P.R. China

E-mail: drzhujinhai@sina.com

${ }^{*}$ Contributed equally

Key words: pancreatic cancer, microRNA-183-5p, SOCS-6, proliferation, invasion, metastasis
miR-183 expression may be beneficial as $\mathrm{PaCa}$ treatment. SOCS-6 is a potential target gene of miR-183.

\section{Introduction}

Pancreatic carcinoma $(\mathrm{PaCa})$ is the fourth leading cause of cancer-related mortality in the USA (1) and is associated with $\sim 227,000$ mortalities per year worldwide (2). It is one of the most aggressive malignancies, with a 5-year survival rate of $<2 \%$ (3). Research has confirmed that PaCa may be considered a disease of genetic mutation, involving tumor-suppressor gene inactivation and oncogene activation (4). Alterations in microRNA (miRNA) expression appear to contribute to pancreatic cancer development and progression; overexpression of a number of miRNAs, including miR-21, miR-34, miR-155 and miR-200, is reported to be important for neoplastic progression (5-8).

miRNAs are a class of small, conservative and endogenous non-coding single-stranded RNAs of 17-24 nucleotides in length. These molecules regulate the expression of protein-coding genes at the translational level via complementary sequences in the 3'-untranslated region (3'UTR) of mRNA: miRNAs form part of an RNA-induced silencing complex (9), which binds to the 3'UTR of a target gene, triggering degradation or preventing translation of the target mRNA $(10,11)$.

miRNA-183 (miR-183) is located on chromosome 7q32 and is dysregulated in numerous types of tumor (12). Studies have demonstrated that miR-183 is involved in the modulation of various cellular processes and is important in the differentiation of malignant tumors (13-15). In addition, miR-183 is involved in the regulatory mechanisms of tumor invasion and metastasis (16). Studies have reported that miR-183 is overexpressed in the majority of tumor types, including breast cancer (17) and prostate cancer (18). A number of experimental studies have found that miRNAs are involved in multiple processes of cancer progression, including cancer cell proliferation and metastasis (19-21). However, we also found that miR-183 is downregulated in certain tumors, such as retinoblastoma (22) and lung cancer (23), and may act as a tumor suppressor. A number of studies have demonstrated that the miR-183 carcinogenic mechanism depends on the regulation of oncogenes or tumor-suppressor genes: Ueno et al (24) identified Dkk-3 and SMAD4 as potential target genes of miR-183, whilst Tanaka et al (25) reported that the upregulation of 
miR-183 in glioblastomas is associated with the expression of hypoxia-inducible factor $1 \alpha$. In addition, Sarver et al (26) confirmed miR-183 acts as an oncogene through regulation of two tumor-suppressor genes, early growth response 1 and phosphatase and tensin homolog.

The literature indicates that miR-183 may be an oncogene in a number of cancer types. High expression levels of miR-183 have also been reported in pancreatic cancer (27); however, the biological characteristics and targets of miR-183 are not well understood. Meanwhile, suppressor of cytokine signaling 6 (SOCS-6) is a known tumor suppressor. Based on findings from target gene detection software (miRDB, PicTar and TargetSCAN), we hypothesized that the differential expression of miR-183 may result in the downregulation of SOCS-6 proteins, which are important mediators of cellular growth, invasion and metastasis.

\section{Materials and methods}

Tissue samples and cell lines. Pancreatic adenocarcinoma tissues and respective adjacent normal ductal epithelial tissues were obtained postoperatively from 24 patients (18 males and 6 females; mean age, 59.8 years; range, 48-75 years), following pancreaticoduodenal resection, who were pathologically diagnosed with stage I disease, according to Hermeck staging (28), at Fujian Medical University Union Hospital (Fuzhou, China) between January 2009 and August 2013. All diagnoses were based on pathological evidence. The tissue samples were paraffin-embedded and stored prior to use. The human pancreatic cancer cell line PANC-1 and pancreatic ductal cell line HPDE6-C7 were obtained from the Institute of Liver and Gallbladder Surgery of Union Hospital, and were maintained in Dulbecco's modified Eagle's medium (DMEM) supplemented with $10 \%$ fetal bovine serum (FBS; Gibco Life Technologies, Grand Island, NY, USA). Cells were grown in an incubator at $37^{\circ} \mathrm{C}$ in a humidified atmosphere of $5 \% \mathrm{CO}_{2}$. This study was approved by the ethics committee of Fujian Medical University Union Hospital.

Target prediction. Target gene detection software, TargetSCAN (http://www.targetscan.org/mamm_31/; Whitehead Institute for Biomedical Research, Cambridge, MA, USA), miRDB (http:// www.mirdb.org/miRDB/) (29) and PicTar (http://www.pictar. org/; Max Delbrück Center for Molecular Medicine, Berlin, Germany) were used to identify complementary sequences between the miR-183-5p and SOCS- 6 genes, using the miRNA gene name 'has-miR-183' to predict miRNA targets.

Cell transfections. The miR-183-5p inhibitor and negative control (NC) gene fragments were obtained from Shanghai GenePharma, Co.. Ltd., (Shanghai, China). Transfections were performed using Lipofectamine 2000 (Invitrogen Life Technologies, Carlsbad, CA, USA) according to the manufacturer's protocol. Cells were grown in 6-well culture plates until 70-80\% confluence. For each well, $5 \mu 1$ human miR-183-5p inhibitor or NC were added to $250 \mu \mathrm{l}$ DMEM with $5 \mu 1$ Lipofectamine 2000. The mixture was added to the cells and incubated for 24-48 h. Total RNA and protein were used for quantitative polymerase chain reaction (qPCR) or western blot analysis following transfection. $q P C R$. Total RNA was extracted from cells using Trizol reagent according to the manufacturer's instructions (Invitrogen Life Technologies). The miR-183-5p and SOCS-6 levels in PANC-1 cells were quantified and validated by qPCR using Maxima ${ }^{\circledR}$ SYBR Green/ROX qPCR Master Mix (2X) (\#K0221; Thermo Fisher Scientific, Pittsburgh, PA, USA), with U6 small nuclear RNA as an internal normalized reference. For mRNA detection, reverse transcription was performed according to the protocol provided with the RevertAid First Strand cDNA Synthesis Kit (\#K1622; Thermo Fisher Scientific). Using GAPDH mRNA levels for normalization, relative levels of miR-183-5p and SOCS-6 were measured in triplicate in a StepOne ${ }^{\mathrm{TM}}$ Real-Time PCR System (Applied Biosystems Life Technologies, Foster City, CA, USA) according to the supplier's instructions. The primers used were as follows: miR-183-5p forward, 5'-CGCGGTATGGCACTGGTAGA-3', and reverse, 5'-AGTGCAGGGTCCGAGGTATTC-3'; U6 forward, 5'-CTCGCTTCGGCAGCACATA-3', and reverse, 5'-CGAATTTGCGTGTCATCCT-3'; SOCS-6 forward, 5'-CCCGAGGATGAGAGTCAGGTAG-3', and reverse, 5'-TGGAGGTAGCAATGGTGAGAGTG-3'; and GAPDH forward, 5'-TGCACCACCAACTGCTTAGC-3', and reverse, 5'-AGCTCAGGGATGACCTTGCC-3'. The qPCR conditions consisted of a uracil-N-glycosylase carry-over protection step of $55^{\circ} \mathrm{C}$ for $2 \mathrm{~min}, 10 \mathrm{~min}$ of DNA polymerase activation at $95^{\circ} \mathrm{C}$, followed by 40 cycles of $95^{\circ} \mathrm{C}$ for $15 \mathrm{sec}$ and $60^{\circ} \mathrm{C}$ for $60 \mathrm{sec}$. The expression level of miRNA was statistically evaluated by a Student's $t$-test using GraphPad Prism 5 software (GraphPad Software, Inc., La Jolla, CA, USA).

Western blotting and immunohistochemistry (IHC). Total protein extracted from the untransfected, miR-183-5p inhibitor-transfected and NC-transfected PANC-1 cells was subjected to $10 \%$ SDS-PAGE (Bio/West, Inc., Salt Lake City, UT, USA) at $80 \mathrm{~V}$ and transferred to polyvinylidene fluoride membranes (Millipore, Billerica, MA, USA) at $120 \mathrm{~V}$. The transferred membranes were blocked for $2 \mathrm{~h}$ with $5 \%$ non-fat powdered milk and incubated with the following primary antibodies, diluted 1:1,000, overnight at $4^{\circ} \mathrm{C}$ : Monoclonal mouse anti-human SOCS6 (\#ab56516; Abcam, Cambridge, MA, USA) and monoclonal mouse anti-human $\beta$-actin antibody (\#sc-47778; Santa Cruz Biotechnology, Inc., Dallas, TX, USA). The membranes were subsequently incubated for $30 \mathrm{~min}$ at room temperature with the respective monoclonal goat anti-mouse horseradish peroxidase-conjugated IgG secondary antibodies (\#A0216; Beyotime Institute of Biotechnology, Shanghai, China; dilution, 1:5,000) following the manufacturer's instructions, and then exposed to X-ray film (Kodak, Rochester, NY, USA). $\beta$-actin levels were used to standardize protein loading, with the assumption that the level of $\beta$-actin would be similar in all cells. IHC (30) was performed with a rabbit polyclonal IgG antibody against human SOCS-6 (\#sc-5608; Santa Cruz Biotechnology, Inc.; dilution, 1:200) and MaxVision ${ }^{\mathrm{TM}}$ HRP-Polymer anti-Mouse IHC Kit (Fuzhou Maixin Biotech, Co., Ltd., Fuzhou, China) using the standard method.

Cell proliferation assay. The Cell Counting Kit-8 (CCK-8; Beyotime Institute of Biotechnology) was used for the detection of cell proliferation. In 96 -well plates, $\sim 10^{3}$ cells per well were incubated in DMEM for $48 \mathrm{~h}$ prior to the addition of $10 \mu \mathrm{l} \mathrm{CCK}-8$ solution. The mixture was incubated at $37^{\circ} \mathrm{C}$ 
for $4 \mathrm{~h}$, during which time CCK-8 was cleaved to an orange formazan dye by metabolically active cells. Following incubation, the absorbance of the formazan product was measured using an enzyme-linked immunosorbent assay reader (550; Bio-Rad Laboratories, Inc., Hercules, CA, USA) at $450 \mathrm{~nm}$.

Wound-healing assay. Pancreatic cancer cells were seeded in 6-well plates and transfected with miR-183-5p inhibitor or NC, or untreated. After $24 \mathrm{~h}$, a wound was formed by scraping the cells with a $20 \mu \mathrm{l}$ pipette tip and washing twice with DMEM. The cells were kept without bovine serum albumin (BSA) in DMEM. Cells were observed at 0 and $48 \mathrm{~h}$ after scraping and images were captured under a microscope (TE2000-U; Nikon Corporation, Tokyo, Japan).

Cell invasion assays. Invasion assays were performed using 24-well transwell chambers ( $8 \mu \mathrm{m}$; Corning Life Sciences, Corning, NY, USA), fibronectin (FN; BD Biosciences, San Jose, CA, USA) and Matrigel ${ }^{\mathrm{TM}}$ (BD Biosciences). The upper chambers were covered with $50 \mathrm{mg} / \mathrm{ml} \mathrm{Matrigel}^{\mathrm{TM}}$ inside and FN outside. PANC-1 cells transfected with miR-183-5p inhibitor or NC were suspended in DMEM without FBS in the upper chambers, and the cell concentration was adjusted to $5 \times 10^{5}$ cells $/ \mathrm{ml}$. Aliquots of the suspension $(\sim 200 \mu \mathrm{l})$ were seeded into the upper chambers, and $1 \mathrm{ml}$ of DMEM containing $10 \%$ FBS was added to the lower chambers. After $48 \mathrm{~h}$, the migrated cells were fixed with $95 \%$ ethanol and $5 \%$ acetic acid before staining with hematoxylin (Beyotime Institute of Biotechnology) for $5 \mathrm{~min}$.

Statistical analysis. Data collected from at least three independent experiments are expressed as the mean \pm standard deviation. Differences between groups were analyzed using two-tailed Student's $t$-test after fitting a normal distribution using an F-test. All tests performed were two-sided. All statistical analyses were performed using GraphPad Prism 5 software and $\mathrm{P}<0.05$ was regarded to indicate statistical significance.

\section{Results}

SOCS- 6 may be a target gene of miR-183. qPCR was used to detect the expression of miR-183 in the PaCa cell line PANC-1 and in the normal pancreatic cell line HPDE6-C7 to confirm whether miR-183-5p is dysregulated in pancreatic cancer. The expression of miR-183-5p in PANC-1 cells was observed to be significantly higher than that in HPDE6-C7 cells $(\mathrm{P}=0.0003$; Fig. 1A).

To establish more regarding the biological relationship between SOCS-6 and miR-183-5p in pancreatic cancer, the miRNA target gene prediction software TargetSCAN was used to forecast the target genes of miR-183-5p. miR-183 was found to be complementary to the 3'-UTR of SOCS-6 (Fig. 1B). qPCR was subsequently used to test SOCS-6 expression in PANC-1 and HPDE6-C7 cells, revealing that SOCS-6 expression was downregulated in PANC-1 compared with HPDE6-C7 (Fig. 1A, P<0.0001). However, transfection of PANC-1 cells with a miR-183-5p inhibitor resulted in an increase in SOCS-6 expression relative to that of untransfected PANC-1 cells (Fig. 1C, P=0.0028).
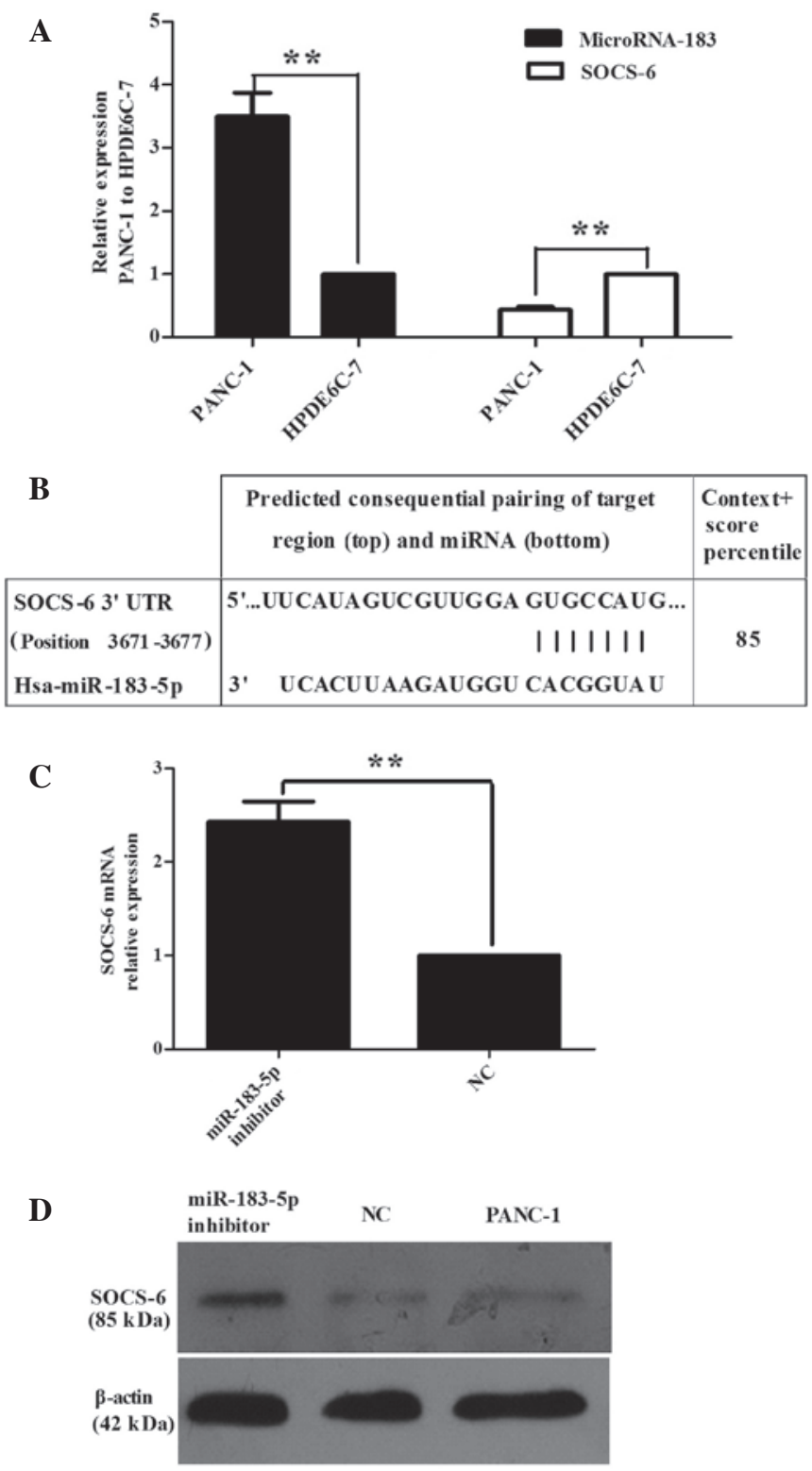

Figure 1. (A) miR-183-5p level was analyzed by qPCR. miR-183-5p expression in PANC-1 pancreatic carcinoma cells was significantly higher than that in HPDE6-C7 normal pancreatic cells $(\mathrm{P}=0.0003)$; however, the SOCS-6 level was downregulated in PANC-1 compared with HPDE6-C7 $(\mathrm{P}<0.0001)$. (B) Complementary sequence between miR-183-5p and SOCS-6 3'-UTR. (C) SOCS-6 expression levels increased markedly in PANC-1 cells transfected with miR-183-5p inhibitor vs. untransfected cells $(\mathrm{P}=0.0028)$, however, the levels of SOCS-6 in PANC-1 cells transfected with NC did not differ from that of untreated PANC-1 cells. The results represent the relative level of SOCS-6 in PANC-1. (D) Western blot analysis revealed that SOCS-6 expression was significantly higher after transfection with a low dose of miR-183 inhibitor than in PANC-1 cells treated with NC or untreated. $\beta$-actin was used as internal reference positive control. miR/miRNA, microRNA; qPCR, quantitative polymerase chain reaction; SOCS-6, suppressor of cytokine signaling 6; NC, negative control; UTR, untranslated region.

Western blot analysis (Fig. 1D) was also used to analyze the change in SOCS-6 expression in cells transfected with the miR-183-5p inhibitor. The outcome was consistent with that of the qPCR. All results indicated that SOCS -6 may be a target gene of miR-183-5p. Thus, further investigation of the changes in SOCS-6 expression in pancreatic cancer tissue must be conducted. 
A

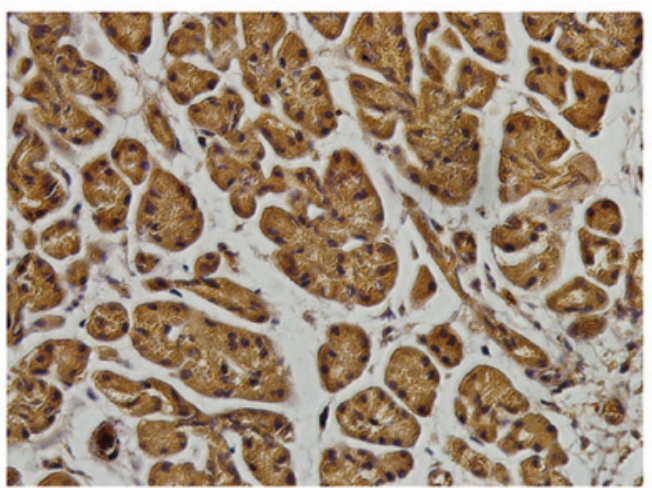

B

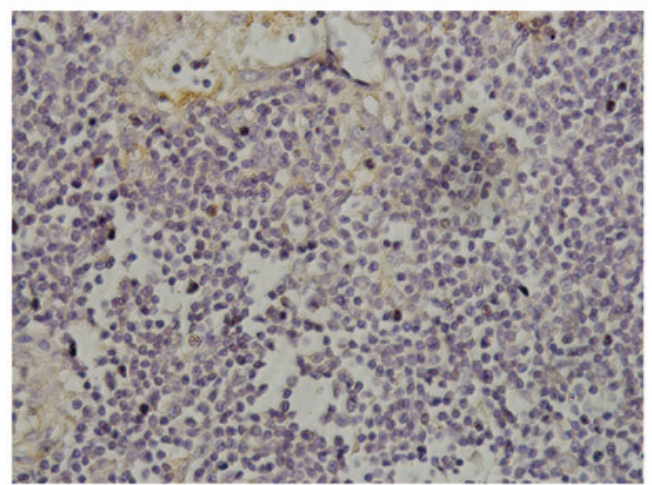

Figure 2. Immunohistochemistry revealed that SOCS-6 expression was significantly higher in (A) PaCa-adjacent normal pancreatic tissue compared with (B) $\mathrm{PaCa}$ tissue. $\mathrm{PaCa}$, pancreatic carcinoma. Magnification, $\mathrm{x} 400$.

A

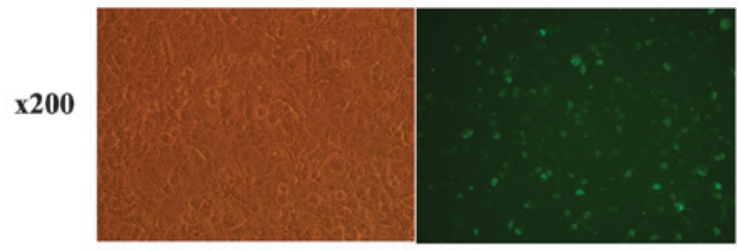

C miR-183-5p

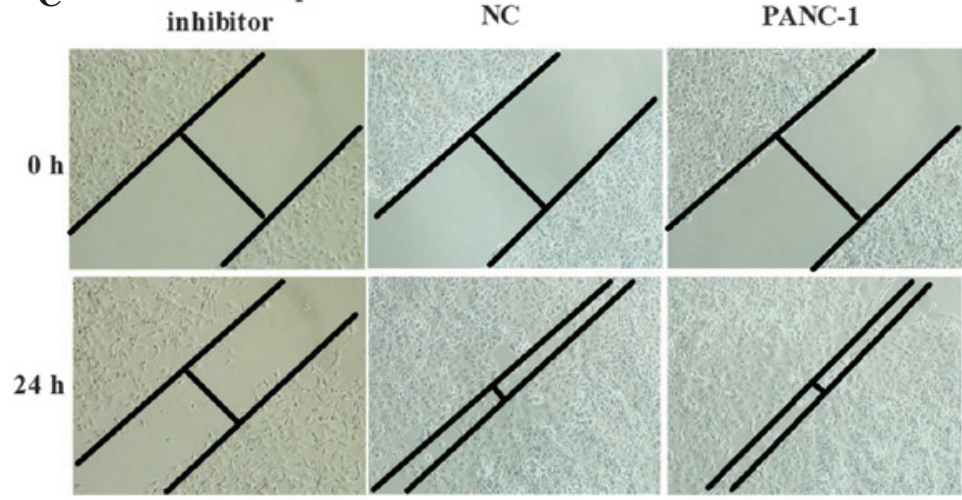

D $\quad$ miR-183-5p inhibitor

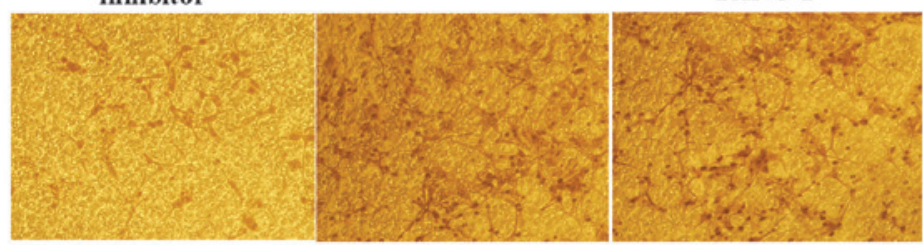

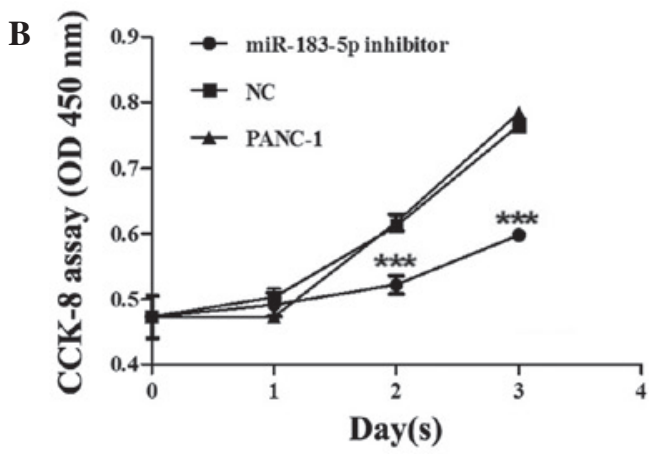
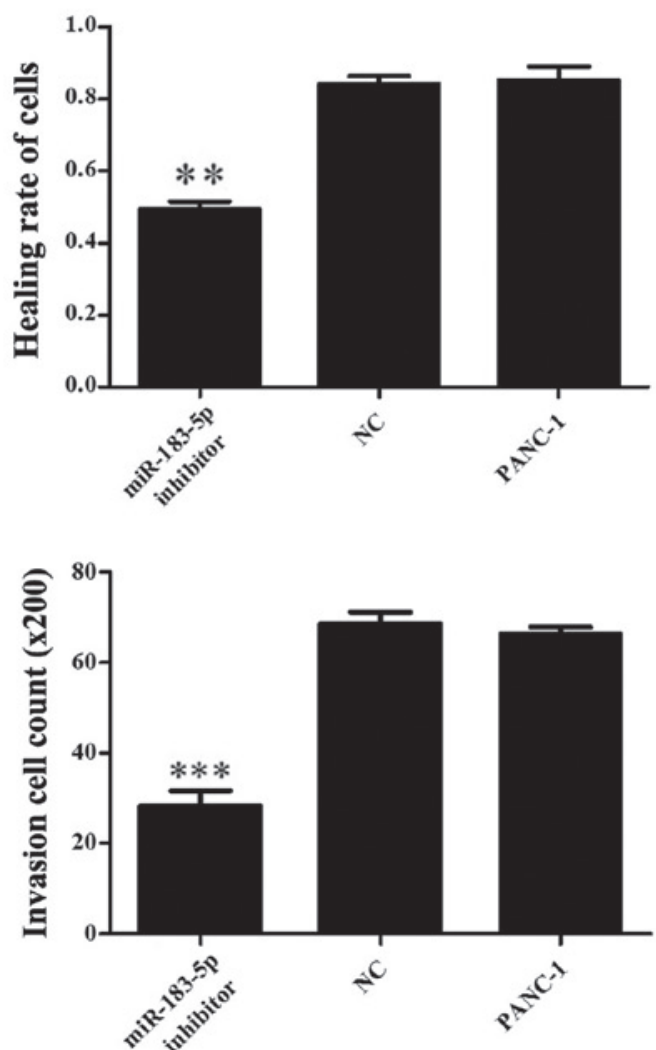

Figure 3. (A) miR-183-5p transfected PANC-1 pancreatic carcinoma cells; the transfection efficiency was $\sim 60 \%$. (B) CCK-8 assay: Cell proliferation decreased significantly in PANC-1 cells transfected with miR-183-5p inhibitor compared with PANC-1 cells transfected with NC $(\mathrm{P}<0.001)$ and untreated PANC-1 cells $(\mathrm{P} \leq 0.001)$. (C) Wound-healing assay: Adhered cell monolayers were scratched with a $20 \mu 1$ pipette tip and wound-healing capacity was monitored by microscope after 0 and $24 \mathrm{~h}$. The wound closure rate of PANC-1 cells transfected with miR-183 inhibitor was significantly lower than that of PANC-1 cells transfected with NC ( $\mathrm{P}=0.0004)$ and untransfected PANC-1 cells $(\mathrm{P}=0.0012)$. (D) PANC-1 cells were transfected with miR-183-5p inhibitor or NC for $48 \mathrm{~h}$; cell invasion ability was measured by Matrigel invasion assays. After transfection with miR-183-5p inhibitor, the PANC-1 cell invasion ability was lower compared with that of untransfected PANC-1 cells $(\mathrm{P}<0.0001)$ or cells transfected with NC $(\mathrm{P}<0.0001)$. miR, microRNA; NC, negative control; CCK-8, cell counting kit-8. 
To further confirm these findings, IHC was performed on $\mathrm{PaCa}$ tissue and adjacent normal pancreatic tissue from $\mathrm{PaCa}$ patients, revealing that SOCS-6 expression was significantly higher in normal pancreatic tissue compared with that in $\mathrm{PaCa}$ cells (Fig. 2). The result is consistent with those of the western blot and qPCR.

Inhibition of miR-183-5p expression inhibits cell proliferation in PANC-1 cells. The SOCS family has been proposed to act predominantly as negative regulator of signaling by cytokines and certain growth factors (31). We hypothesized that SOCS6 is a direct target of miRNA-183-5p and, therefore, that miR-183-5p is likely to be connected with tumor proliferation. To confirm this, CCK- 8 assays were performed in PANC-1 human $\mathrm{PaCa}$ cells, which highly express miR-183-5p. The miR-183-5p inhibitor was observed to reduce cell proliferation at 1-3 days after transfection (transfection efficiency, $60 \%$; Fig. 3A) compared with the NC-transfected and untransfected PANC-1 cells $(\mathrm{P} \leq 0.001$; Fig. 3B), which remained similar throughout the $72 \mathrm{~h}$ assay period. These results indicate that anti-miR-183-5p may repress the proliferation of PANC-1 cells.

Inhibition of miR-183-5p expression represses PANC-1 cell migration and invasion. To study the role of miR-183-5p in the invasion and metastasis of pancreatic cancer, a transwell assay and wound healing/scratch test were used to detect the capacity of invasion and migration in PANC-1 cells following transfection with a miR-183-5p inhibitor. As shown in Fig. 2C, transfection with the miR-183-5p inhibitor reduced the migratory ability of PANC-1 cells compared with the untreated $(\mathrm{P}=0.0012)$ and $\mathrm{NC}$ cells $(\mathrm{P}=0.0004)$. Invasive capacity was also repressed by the miR-183-5p inhibitor compared with that in $\mathrm{NC}$ and untreated cells $(\mathrm{P}<0.001$; Fig. 2D). These results indicate that downregulation of miR-183-5p inhibits the migration and invasion of PANC-1 cells in vitro.

\section{Discussion}

Various miRNAs have been reported to be dysregulated in $\mathrm{PaCa}$; these molecules may function as tumor-suppressor genes (Let-7, miR-20a, miR-143) (32-34) or oncogenes (miR-181, miR-21, miR-10a, miR-196a) (30,35-40). A number of these miRNAs are associated with the invasive and metastatic abilities of pancreatic cancer cells. For example, downregulation of miR-218 has been demonstrated in PANC-1 cells. Forced expression of miR-218 was found to inhibit cell migration and invasion in a roundabout homolog 1 (ROBO1)-dependent manner and ROBO1 has previously been identified as a functional target of miRNA-218's downstream pathway, which is involved in the invasion and migration of pancreatic cancer (41). miR-26a has also been reported to impair cell migration, invasion and apoptosis in PANC-1 cells by controlling the expression of high mobility group AT-hook 1 (HMGA1); the authors demonstrated that the oncogene HMGA1 was a direct target of miR-26a (42). In addition, a previous study revealed that expression of miR-126 was promoted in pancreatic carcinoma cells, and the expression of the tumor suppressor gene, disintegrin and metalloproteinase domain-containing protein 9 (ADAM9), was suppressed; blocking miR-126 decreased migration and invasion (43). These results indicated that the miR-126/ADAM9 axis exerts a critical role in pancreatic carcinoma (43). Another previous study showed that endogenous miR-224 and miR-468 inhibited the expression of the tumor suppressor gene, CD40, in PANC-1 and promoted cell metastasis and invasion, indicating that they exhibited an important role in the progression of pancreatic cancer (44). These findings demonstrate that miRNA expression is dysregulated in $\mathrm{PaCa}$ cell lines, and miRNAs may promote or inhibit $\mathrm{PaCa}$ cell migration and invasion by targeting certain mRNAs.

Invasion and metastasis are the main determinants of poor prognosis in pancreatic cancer (7). The functional study of miR-183 in malignancy has been previously reported in most tumors $(15,45-47)$. miR-183 is downregulated in HeLa cells, and has been demonstrated to mediate the invasive and metastatic ability of HeLa cells by directly targeting integrin $\beta 1$ (48). miR-183 is likely to have numerous targets via which it modulates biological functions in cancer cells $(45,46,49)$. However, miR-183 is rarely reported in similar research reports regarding pancreatic carcinoma and did not show relevant biological characteristics and molecular mechanisms. In the current study, the expression of miR-183-5p was found to be significantly upregulated in PaCa cell lines, whilst expression of SOCS-6 was markedly downregulated in $\mathrm{PaCa}$ tissues and cell lines. To investigate the mechanism by which miR-183 may promote the metastasis of $\mathrm{PaCa}$, the miRNA target prediction programs TargetScan, PicTar and miRDB were employed to identify the direct targets of miR-183 (50). All three programs predicted SOCS -6 to be a target of miR-183. To verify the effect of miR-183 on SOCS-6 expression, a miR-183 inhibitor was transfected into PANC-1 cells. Notably, following transfection with the miR-183 inhibitor, SOCS-6 expression these cells increased significantly, as indicated by qPCR and western blot analysis. By contrast, PANC-1 cells transfected with $\mathrm{NC}$ or without transfection exhibited no significant change in SOCS-6 expression. The current study also found that suppressing the expression of miR-183-5p significantly repressed the proliferative, invasive and metastatic abilities of PANC-1 cells. Taken together, these findings suggest that miR-183 may promote proliferation, invasion and migration of PaCa cells. In addition, SOCS-6 expression is inversely associated with the proliferation, invasion and migration of PaCa cells. By downregulating SOCS-6, miR-183 may act as an accelerant factor in the progression of $\mathrm{PaCa}$ cells.

The SOCS family of proteins consist of eight members: SOCS1 to SOCS7 and cytokine-inducible SH2-containing protein (CISH) (51). Similar to other SOCS family members, the degradation of target proteins is the predominant regulatory effect of SOCS-6 (52). Sriram et al (53) reported that loss of SOCS-6 is associated with significantly shorter overall survival time in lung small cell carcinoma. The downregulation of SOCS-6 mRNA expression has been observed in $>50 \%$ of patients with gastric or colorectal cancer $(54,55)$. Wu et al $(56)$ proposed that SOCS-6 is a tumor-suppressor gene in pancreatic cancer. Through the collection of clinical specimens and detecting SOCS-6 expression, the present study identified a significant reduction in 
SOCS-6 expression in pancreatic cancer tissues compared with that of adjacent normal pancreatic tissues. This result was consistent with that of Wu et al, which also demonstrated that SOCS-6 was downregulated in pancreatic cancer.

In the current study, the expression level of miR-183-5p was observed to be inversely correlated with SOCS-6 expression in PaCa cell lines. To the best of our knowledge, this study is the first in vitro study to demonstrate the regulation of metastasis and progression of $\mathrm{PaCa}$ cell lines by downregulation of miR-183-5p to target the expression of SOCS-6. The expression of miR-183-5p in PaCa cell lines is consistent with the study by Park et al (57), which revealed that miR-183 was upregulated in pancreatic cancer. The findings of the current study indicate a promotional role for miR-183 in cell proliferation, migration and invasion of $\mathrm{PaCa}$ cells by downregulating SOCS-6. This may provide an important basis for further analysis in vivo with the aim of developing a novel potential diagnostic and therapeutic target for the screening and treatment of metastatic $\mathrm{PaCa}$. Further studies are necessary in order to elucidate the regulatory mechanisms of miR-183-5p and SOCS-6 in PaCa cells, in vitro and in vivo.

In conclusion, the present study has demonstrated the upregulation of miR-183-5p in PaCa cell lines compared with normal pancreatic cancer cells, and in vitro experiments indicated that this miRNA was able to enhance the proliferation, migration and invasion of $\mathrm{PaCa}$ cells. Downregulation of miR-183-5p partially attenuated oncogenic effects, indicating that this molecule may act as an oncogene. In addition, SOCS-6 was identified as a target of miR-183-5p, and may present a potential target for $\mathrm{PaCa}$ therapy. Therefore, miR-183-5p may be a key molecule for the diagnosis and treatment of pancreatic cancer in the future.

\section{Acknowledgements}

This study was supported by grants from the Key Project of Science and Technology Research Program in Fujian Province (no. 2014J01323) and the National Clinical Key Specialty Construction Project (General Surgery) of China.

\section{References}

1. Siegel R, Naishadham D and Jemal A: Cancer statistics. CA Cancer J Clin 63: 11-30, 2013.

2. Raimondi S, Maisonneuve P and Lowenfels AB: Epidemiology of pancreatic cancer: An overview. Nat Rev Gastroenterol Hepatol 6 : 699-708, 2009.

3. Li D, Xie K, Wolff R and Abbruzzese JL: Pancreatic cancer. Lancet 363: 1049-1057, 2004.

4. Maitra A, Kern SE and Hruban RH: Molecular pathogenesis of pancreatic cancer. Best Pract Res Clin Gastroenterol 20 211-226, 2006.

5. Szafranska AE, Doleshal M, Edmunds HS, Gordon S, Luttges J, Munding JB, Barth RJ Jr, Gutmann EJ, Suriawinata AA and Marc Pipas J: Analysis of microRNAs in pancreatic fine-needle aspirates can classify benign and malignant tissues. Clin Chem 54: $1716-1724,2008$

6. Li A, Omura N, Hong SM, Vincent A, Walter K, Griffith M, Borges $\mathrm{M}$ and Goggins $\mathrm{M}$ : Pancreatic cancers epigenetically silence SIP1 and hypomethylate and overexpress miR-200a/200b in association with elevated circulating miR-200a and miR-200b levels. Cancer Res 70: 5226-5237, 2010.

7. Bloomston M, Frankel WL, Petrocca F, et al: MicroRNA expression patterns to differentiate pancreatic adenocarcinoma from normal pancreas and chronic pancreatitis. JAMA 297: 1901-1908, 2007.
8. Kent OA, Mullendore M, Wentzel EA, López-Romero P, Tan AC, Alvarez H, West K, Ochs MF, Hidalgo M and Arking DE: A resource for analysis of microRNA expression and function in pancreatic ductal adenocarcinoma cells. Cancer Biol Ther 8: 2013-2024, 2009.

9. Sarkar S, Dubaybo H, Ali S, Goncalves P, Kollepara SL, Sethi S, Philip PA and Li Y: Down-regulation of miR-221 inhibits proliferation of pancreatic cancer cells through up-regulation of PTEN, p27 (kip1), p57 (kip2) and PUMA. Am J Cancer Res 3: 465-477, 2013.

10. Bartel DP: MicroRNAs: Genomics, biogenesis, mechanism, and function. Cell 116: 281-297, 2004.

11. He L and Hannon GJ: MicroRNAs: Small RNAs with a big role in gene regulation. Nat Rev Genet 5: 522-531, 2004.

12. Lumayag S, Haldin CE, Corbett NJ, et al: Inactivation of the microRNA-183/96/182 cluster results in syndromic retinal degeneration. Proc Natl Acad Sci USA 110: E507-E516, 2013.

13. Leung WK, He M, Chan AW, Law PT and Wong N: Wnt/ $\beta$-Catenin activates MiR-183/96/182 expression in hepatocellular carcinoma that promotes cell invasion. Cancer Lett 362: 97-105, 2015.

14. Zhang L, Quan H, Wang S, Li X and Che X: MiR-183 promotes growth of non-small cell lung cancer cells through FoxO1 inhibition. Tumour Biol: May 17, 2015 (Epub ahead of print).

15. Zhang Q, Di W, Dong Y, et al: High serum miR-183 level is associated with poor responsiveness of renal cancer to natural killer cells. Tumour Biol: Jun 20, 2015 (Epub ahead of print).

16. Kundu ST, Byers LA, Peng DH, et al: The miR-200 family and the miR-183 96 182 cluster target Foxf2 to inhibit invasion and metastasis in lung cancers. Oncogene: Mar 23, 2015 (Epub ahead of print).

17. Ouyang M, Li Y, Ye S, Ma J, Lu L, Lv W, Chang G, Li X, Li Q, Wang S and Wang W: MicroRNA profiling implies new markers of chemoresistance of triple-negative breast cancer. PLoS One 9: e96228, 2014.

18. Mihelich BL, Khramtsova EA, Arva N, Vaishnav A, Johnson DN, Giangreco AA, Martens-Uzunova E, Bagasra O, Kajdacsy-Balla A and Nonn L: MiR-183-96-182 cluster is overexpressed in prostate tissue and regulates zinc homeostasis in prostatecells. J Biol Chem 286: 44503-44511, 2011.

19. Ventura A and Jacks T: MicroRNAs and cancer: Short RNAs go a long way. Cell 136: 586-591, 2009.

20. Wojtas B, Ferraz C, Stokowy T, Hauptmann S, Lange D, Dralle H, Musholt T, Jarzab B, Paschke R and Eszlinger M: Differential miRNA expression defines migration and reduced apoptosis in follicular thyroid carcinomas. Mol Cell Endocrinol 388: $1-9,2014$

21. Lowery AJ, Miller N, Dwyer RM and Kerin MJ: Dysregulated miR-183 inhibits migration in breast cancer cells. BMC Cancer 10: 502, 2010.

22. Wang J, Wang X, Li Z, Liu H and Teng Y: MicroRNA-183 suppresses retinoblastoma cell growth, invasion and migration by targeting LRP6. FEBS J 281: 1355-1365, 2014.

23. Wang G, Mao W and Zheng S: MicroRNA-183 regulates Ezrin expression in lung cancer cells. FEBS Lett 582: 3663-3668, 2008

24. Ueno K, Hirata H, Shahryari V, Deng G, Tanaka Y, Tabatabai ZL, Hinoda Y and Dahiya R: MicroRNA-183 is an oncogene targeting Dkk-3 and SMAD4 in prostate cancer. Br J Cancer 108: 1659-1667, 2013

25. Tanaka H, Sasayama T, Tanaka K, et al: MicroRNA-183 upregulates HIF- $1 \alpha$ by targeting isocitrate dehydrogenase 2 (IDH2) in glioma cells. J Neurooncol 111: 273-283, 2013.

26. Sarver AL, Li L and Subramanian S: MicroRNA miR-183 functions as an oncogene by targeting the transcription factor EGR 1 and promoting tumor cell migration. Cancer Res 70: 9570-9580, 2010.

27. Park YG, Lee KH, Lee JK, et al: MicroRNA expression pattern in intraductal papillary mucinous neoplasm. Korean J Gastroenterol 58: 190-200, 2011 (In Korean).

28. Wong $\mathrm{N}$ and Wang X: miRDB: An online resource for microRNA target prediction and functional annotations. Nucleic Acids Res 43: D146-D152, 2015.

29. Jia A, Xiao J and Liu X: Serum tumor marker CA199, CA125, CA242 and CEA. Correlational analysis and detection of different stages of pancreatic cancer. Chongqing Med 35: 3605-3607, 2011 (In Chinese).

30. Hwang JH, Voortman J, Giovannetti E, et al: Identification of microRNA-21 as a biomarker for chemoresistance and clinical outcome following adjuvant therapy in resectable pancreatic cancer. PloS One 5: e10630, 2010. 
31. Trengove MC and Ward AC: SOCS proteins in development and disease. Am J Clin Exp Immunol 2: 1-29, 2013.

32. Torrisani J, Bournet B, du Rieu MC, Bouisson M, Souque A, Escourrou J, Buscail L and Cordelier P: Let-7 microRNA transfer in pancreatic cancer-derived cells inhibits in vitro cell proliferation but fails to alter tumor progression. Hu Gene Ther 20 : 831-844, 2009.

33. Yan H, Wu J, Liu W, Zuo Y, Chen S, Zhang S, Zeng M and Huang W: MicroRNA-20a overexpression inhibited proliferation and metastasis of pancreatic carcinoma cells. Hum Gene Ther 21: 1723-1734, 2010.

34. Hu Y, Ou Y, Wu K, Chen Y and Sun W: miR-143 inhibits the metastasis of pancreatic cancer and an associated signaling pathway. Tumour Biol 33: 1863-1870, 2012.

35. Bloomston M, Frankel WL, Petrocca F, Volinia S, Alder H, Hagan JP, Liu CG, Bhatt D, Taccioli C and Croce CM: MicroRNA expression patterns to differentiate pancreatic adenocarcinoma from normal pancreas and chronic pancreatitis. JAMA 297: 1901-1908, 2007.

36. Panarelli NC, Chen YT, Zhou XK, Kitabayashi N and Yantiss RK: MicroRNA expression aids the preoperative diagnosis of pancreatic ductal adenocarcinoma. Pancreas 41: 685-690, 2012.

37. Wang J1, Chen J, Chang P, LeBlanc A, Li D, Abbruzzesse JL, Frazier ML, Killary AM and Sen S: MicroRNAs in plasma of pancreatic ductal adenocarcinoma patients as novel blood-based biomarkers of disease. Cancer Prev Res (Phila) 2: 807-813, 2009.

38. Dillhoff M, Liu J, Frankel W, Croce C and Bloomston M: MicroRNA-21 is overexpressed in pancreatic cancer and a potential predictor of survival. J Gastrointest Surg 12: 2171-2176, 2008.

39. Moriyama T, Ohuchida K, Mizumoto K, Yu J, Sato N, Nabae T, Takahata S, Toma H, Nagai E and Tanaka M: MicroRNA-21 modulates biological functions of pancreatic cancer cells including their proliferation, invasion and chemoresistance. Mo Cancer Ther 8: 1067-1074, 2009.

40. Moriyama T, Ohuchida K, Mizumoto K, Yu J, Sato N, Nabae T, Takahata S, Toma H, Nagai E and Tanaka M: MicroRNA-10a is overexpressed in human pancreatic cancer and involved in its invasiveness partially via suppression of the HOXA1 gene. Ann Surg Oncol 19: 2394-2402, 2012

41. He H, Hao SJ, Yao L, Yang F, Di Y, Li J, Jiang YJ, Jin C and Fu DL: MicroRNA-218 inhibits cell invasion and migration of pancreatic cancer via regulating ROBO1. Cancer Biol Ther 15: 1333-1339, 2014

42. Li W, Yuan Y, Huang L, Qiao M and Zhang Y: Metformin alters the expression profiles of microRNAs in human pancreatic cancer cells. Diabetes Res Clin Pract 96: 187-195, 2012.

43. Hamada S, Satoh K, Fujibuchi W, Hirota M, Kanno A, Unno J, Masamune A, Kikuta K, Kume K and Shimosegawa T: MiR-126 acts as a tumor suppressor in pancreatic cancer cells via the regulation of ADAM9. Mol Cancer Res 10: 3-10, 2012

44. Mees ST, Mardin WA, Sielker S, Willscher E, Senninger N, Schleicher C, Colombo-Benkmann M and Haier J: Involvement of CD40 targeting miR-224 and miR-486 on the progression of pancreatic ductal adenocarcinomas. Ann Surg Oncol 16: 2339-2350, 2009.
45. Chang CW, Wu HC, Terry MB and Santella RM: microRNA expression in prospectively collected blood as a potential biomarker of breast cancer risk in the BCFR. Anticancer Res 35: 3969-3977, 2015.

46. Pak MG, Lee CH, Lee WJ, Shin DH and Roh MS: Unique microRNAs in lung adenocarcinoma groups according to major TKI sensitive EGFR mutation status. Diagn Pathol 10: 99, 2015.

47. Van Keuren-Jensen K, Malenica I, Courtright A, et al: microRNA changes in liver tissue associated with fibrosis progression in patients with Hepatitis-C. Liver Int: Jul 19, 2015 (Epub ahead of print).

48. Li G, Luna C, Qiu J, Epstein DL and Gonzalez P: Targeting of integrin betal and kinesin 2alpha by microRNA 183. J Biol Chem 285: 5461-5471, 2010.

49. Cao Z, Zhang N, Lou T, et al: microRNA-183 down-regulates the expression of $\mathrm{BKCa} \beta 1$ protein that is related to the severity of chronic obstructive pulmonary disease. Hippokratia 18: 328-332, 2014

50. Krek A, Grün D, Poy MN, Wolf R, Rosenberg L, Epstein EJ, MacMenamin P, da Piedade I, Gunsalus KC, Stoffel M and Rajewsky N: Combinatorial microRNA target predictions. Nat Genet 37: 495-500, 2005.

51. Hilton DJ, Richardson RT, Alexander WS, Viney EM, Willson TA, Sprigg NS, Starr R, Nicholson SE, Metcalf D and Nicola NA: Twenty proteins containing a C-terminal SOCS box form five structural classes. Proc Natl Acad Sci USA 95: 114-119, 1998

52. Krebs DL, Uren RT, Metcalf D, Rakar S, Zhang JG, Starr R, De Souza DP, Hanzinikolas K, Eyles J, Connolly LM, et al: SOCS-6 binds to insulin receptor substrate 4 and mice lacking the SOCS-6 gene exhibit mild growth retardation. Mol Cell Biol 22: 4567-4578, 2002.

53. Sriram KB, Larsen JE, Savarimuthu Francis SM, Wright CM, Clarke BE, Duhig EE, Brown KM, Hayward NK, Yang IA, Bowman RV and Fong KM: Array-comparative genomic hybridization reveals loss of SOCS6 is associated with poor prognosis in primary lung squamous cell carcinoma. PLoS One 7: e30398, 2012.

54. Lai RH, Hsiao YW, Wang MJ, Lin HY, Wu CW, Chi CW, Li AF, Jou YS and Chen JY: SOCS6, down-regulated in gastric cancer, inhibits cell proliferation and colony formation. Cancer Lett 288: 75-85, 2010

55. Storojeva I, Boulay JL, Heinimann K, Ballabeni $P$, Terracciano L, Laffer U, Mild G, Herrmann R and Rochlitz C: Prognostic and predictive relevance of microsatellite instability in colorectal cancer. Oncol Rep 14: 241-249, 2005.

56. $\mathrm{Wu} \mathrm{K}, \mathrm{Hu}$ G, He X, Zhou P, Li J, He B and Sun W: MicroRNA-424-5p suppresses the expression of SOCS6 in pancreatic cancer. Pathol Oncol Res 19: 739-748, 2013.

57. Park YG, Lee KH, Lee JK, Lee KT, Choi DW, Choi SH, Heo JS, Jang KT, Lee EM, Kim JO, et al: MicroRNA expression pattern in intraductal papillary mucinous neoplasm. Korean J Gastroenterol 58: 190-200, 2011 (In Korean). 